\title{
Use of Electronic Cigarettes in European Populations: A Narrative Review
}

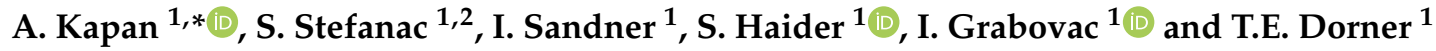 \\ 1 Department of Social and Preventive Medicine, Centre of Public Health, Medical University of Vienna, \\ Vienna 1090, Austria; sinisa.stefanac@meduniwien.ac.at (S.S.);n1140406@students.meduniwien.ac.at (I.S.); \\ sandra.a.haider@meduniwien.ac.at (S.H.); igor.grabovac@meduniwien.ac.at (I.G.); \\ thomas.dorner@meduniwien.ac.at (T.E.D.) \\ 2 Institute of Outcomes Research, Centre for Medical Statistics, Informatics and Intelligent Systems, Medical \\ University of Vienna, Vienna 1090, Austria \\ * Correspondence: ali.kapan@meduniwien.ac.at
}

Received: 21 January 2020; Accepted: 12 March 2020; Published: 17 March 2020

\begin{abstract}
The increasing popularity of electronic cigarettes in past decades has aroused public health concern. This study aims to review the literature on the prevalence of e-cigarette use among the general adult and young populations in Europe. We searched Medline and Google Scholar from September 2019, and included "prevalence of e-cigarettes", "electronic cigarettes" or "e-cigarettes", and "electronic nicotine delivery system" or "vaping". The prevalence of current e-cigarette use ranged from $0.2 \%$ to $27 \%$, ever-use ranged from $5.5 \%$ to $56.6 \%$ and daily use ranged from $1 \%$ to $2.9 \%$. Current smokers of conventional cigarettes showed the highest prevalence for the use of e-cigarettes, ranging from $20.4 \%$ to $83.1 \%$, followed by ex-smokers, with ranges from $7 \%$ to $15 \%$. The following socio-demographic factors were associated with a higher chance of using e-cigarettes: male sex and younger age groups; results for economic status were inconclusive. In European countries, there is a higher prevalence of e-cigarette use among males, adolescents and young adults, smokers of conventional cigarettes, and former smokers.
\end{abstract}

Keywords: prevalence; e-cigarettes; current and ever-use; trend

\section{Introduction}

Electronic nicotine delivery systems (ENDS) are marketed under a variety of names, most commonly-referred to as "electronic cigarettes (e-cigarettes)," but also as "e-cigs", "vapes", "vape pens", and "mods". These different types of electronic nicotine delivery systems are designed to be either less harmful than regular cigarettes or used as nicotine replacement therapy (NRT) [1]. The electronic nicotine device generally consists of a power source, usually a battery, and a heating element that creates an aerosol that is inhaled by the user after the e-liquid (the solution inside a device) has been heated to a temperature of above $350^{\circ} \mathrm{C}[2,3]$.

There is currently active debate about benefits and harms of e-cigarettes at the individual and population level. First, there is uncertainty and debate about the degree to which e-cigarettes help existing smokers to quit. The latest Cochrane Database Systematic Review and meta-analysis found that participants using nicotine-containing e-cigarettes are approximately two-and-a-half times more likely to have abstained from smoking for at least 6 months, compared to those using placebo e-cigarettes. However, the authors have also noted an overall lack of studies and found that the available studies were of low quality and had generally small sample sizes [4]. A limited number of randomized clinical trials evaluating e-cigarette use for smoking cessation have been published [5-7], and the results are conflicting. The latest study mentioned above showed that e-cigarettes were more effective than 
NRT [7]. However, it is important to note that this study also differs from an earlier trial [5] in that participants demonstrated motivation to quit a priori. Moreover, given the constant emergence of new studies, our as-of-yet unpublished meta-analysis found that e-cigarettes with nicotine showed a tendency to be effective in smoking cessation, as compared to placebo e-cigarettes without nicotine. However, the level of evidence was moderate to low, and the analysis results were not significant [8].

Further, little common ground is found among health organizations regarding the question of e-cigarette use in smoking cessation. For example, Public Health England supports e-cigarette use for smoking cessation [9], whereas US health agencies concluded there is insufficient evidence to recommend e-cigarettes use for cessation $[10,11]$. The National Academies of Sciences raised concerns due to unanswered questions regarding long-term health effects in users, as reports suggest that e-cigarettes may damage various organ systems [12]. Moreover, the Centers for Disease Control and Prevention (CDC) has declared an ongoing epidemic of e-cigarette or vaping use associated with lung injury (EVALI) throughout the United States [13,14]. As of 7 January 2020, vaping-related lung injuries have caused 57 confirmed deaths in 27 states and the District of Columbia. Data show that vitamin E acetate, an additive in some tetrahydrocannabinol- (THC) containing e-cigarettes, is strongly linked to the EVALI outbreak, while vitamin E acetate has not been found in the lung fluid of people that do not have EVALI. For this reason, the CDC recommends that people not use e-cigarette products that contain THC [15].

While vaping e-cigarettes may represent a form of harm reduction for adult smokers, there are concerns about potential harm for adolescents, including the risk that ENDS use may act as a gateway to smoking cigarettes among young people [16]. As a meta-analysis from 2016 shows, among never-smoking adolescents and young adults, e-cigarette use was associated with increased smoking intention, as compared to peers who did not use e-cigarettes [17].

In order to estimate the impact of e-cigarettes (both positive and negative), it is important to understand the prevalence of e-cigarette use in the general population. Several studies on the prevalence of e-cigarette use have been already published [18-21]. However, these are mostly based in the United States of America, with few focusing on the European continent. This may be problematic as cultural and public health differences may prohibit generalizations of US-based results on the European context. Furthermore, with the growing availability of e-cigarettes, an update of the prevalence is important [22]. In light of such a rise in scientific interest and the number of publications, we aim to carry out a narrative review of the available literature on e-cigarette use in European population.

\section{Materials and Methods}

In order to perform a narrative review of available literature on prevalence of e-cigarette use, we conducted a literature review in September 2019 in Medline and Google Scholar using the terms "prevalence of electronic cigarettes use", "e-cigarettes use", "electronic nicotine delivery system", "vaping", and "frequency of e-cigarette use". The reference lists of articles that were found were additionally screened for potential articles.

The retrieved articles were screened for content and were selected if (1) they were written in English, if (2) the data provided population-based estimates of e-cigarette use in adults and/or adolescents from one-or more countries of the WHO European region, and (3) if the article was published in a peer-reviewed journal (4) between 2011 and 2019. Full text articles were obtained only if the abstracts included data about the prevalence of e-cigarettes with a cross-sectional or a longitudinal design. Collectively, we summarized the results describing the themes relevant to prevalence and factors of e-cigarette use. If more studies on the same prevalence data were given, data were shown in ranges (minimum to maximum as percentage); otherwise the prevalence values were shown as single percentages. 


\section{Results}

Overall, 22 studies were included in the review (Table 1). Of these, 4 of them included data from multiple countries [22-25], and 18 studies presented data from single countries [26-43]. All included studies were either cross-sectional studies, or cross-sectional baseline findings of longitudinal studies. The sample sizes ranged from 726 to 27901 subjects. 
Table 1. Prevalence of e-cigarette use among the general population.

Citation Data Source Country

\begin{tabular}{ccc}
\hline Citation & Data Source & Country \\
\hline
\end{tabular}
European Commission, Special
Eurobarometer 2017 [22]
2017 Eurobarometer survey
28 Member States of the European Union

Sample Characteristics

\section{Findings}

Respondents who have at least tried e-cigarettes: $15^{\circ}$

- Respondents who have tried them once or twice but do not use them currently: $9 \%$ overall

- Respondents who currently use e-cigarettes or similar electronic devices: $2 \%$

- $67 \%$ of current users used e-cigarettes daily, $20 \%$ reported weekly use, $7 \%$ monthly and $6 \%$ stated using e-cigarettes less than monthly;

ly e-cigarette users: $1 \%$

- Respondents who used to use them but do not use them anymore: $4 \%$

Current conventional smokers:

- who currently use e-cigarettes or similar devices: $4 \%$ in EU28 who used to use e-cigarettes but no longer do so: $10 \%$ in EU2 who tried e-cigarettes once or twice: $23 \%$ in EU28,

- Ex-smokers:

27901 respondents from different social and
demographic groups who currently use e-cigarettes or similar devices: $4 \%$ in EU28 who used to use e-cigarettes but no longer do so: $4 \%$ in EU28 who tried e-cigarettes once or twice: $7 \%$ in EU28,

- Never-smokers:

who currently use e-cigarettes or similar devices: $0 \%$ in EU28 who used to use e-cigarettes but no longer do so: $1 \%$ in EU28 who tried e-cigarettes once or twice: $2 \%$ in EU28,

- Among respondents who have at least tried e-cigarettes socio-demographic differences show highest prevalence among:

men $(17 \%)$ compared to women $(12 \%)$

those aged 15-24 (25\%) followed by $25-39(21 \%), 40-54(15 \%)$ and $55+(6 \%)$

participants that were still studying $(19 \%)$ followed by those who left full time education a the age of $16-19(16 \%)$ age $20+(14 \%)$ and age 15 and before $(8 \%)$

manual workers ( $29 \%)$, the unemployed $(25 \%$, students $(19 \%)$, and the self-employed $(18 \%)$ followed by other white collars $(16 \%)$, managers $(12 \%)$, household persons $(8 \%)$ and the retired $(6 \%)$

hose who stated having difficulties paying bills "most of the time" (23\%) compared to those 
Table 1. Cont.

\begin{tabular}{|c|c|c|c|c|}
\hline Citation & Data Source & Country & Sample Characteristics & Findings \\
\hline Laverty et al. 2016 [23] & $\begin{array}{l}2014 \text { and } 2017 \text { Adult Special } \\
\text { Eurobarometer for } \\
\text { Tobacco Survey }\end{array}$ & $\begin{array}{l}28 \text { Member States of the } \\
\text { European Union }\end{array}$ & $\begin{array}{l}\text { 2014: } 27801 \text { respondents } \\
\text { 2017: } 27901 \text { respondents as } \\
\text { representative samples of the } \\
\text { population aged } \geq 15 \text { years in } \\
\text { each of the } 28 \mathrm{EU} \text { member states } \\
\text { and across the EU in terms of } \\
\text { age, gender and area of } \\
\text { residence. }\end{array}$ & 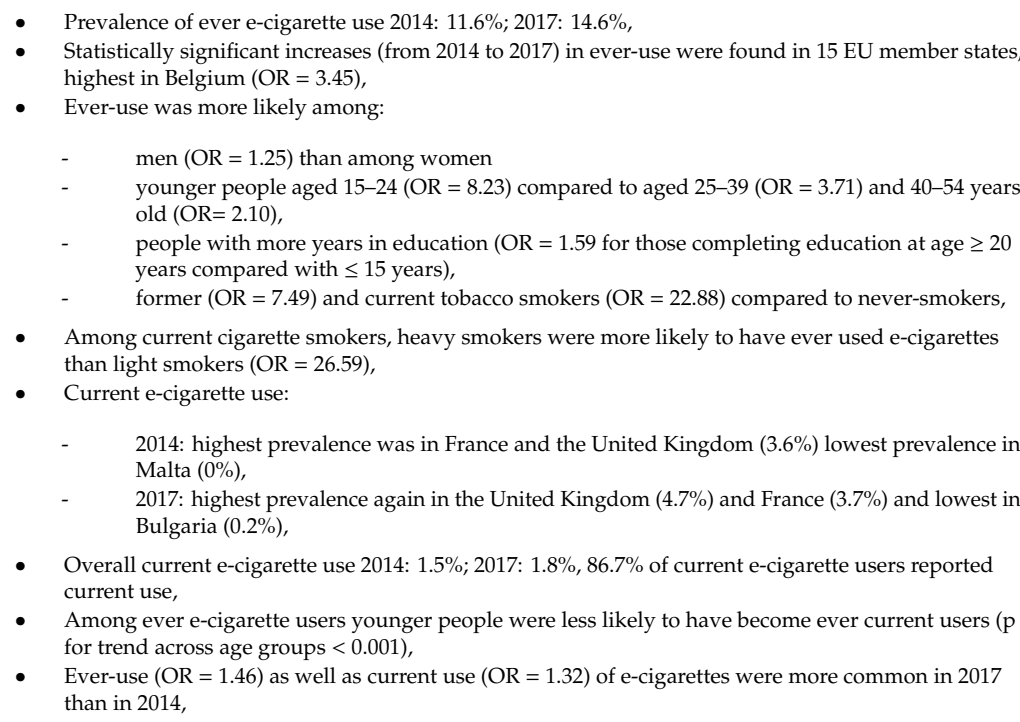 \\
\hline Filippidis et al. 2017 [24] & $\begin{array}{c}2012 \text { and } 2014 \text { Adult Special } \\
\text { Eurobarometer for Tobacco } \\
\text { Survey }\end{array}$ & $\begin{array}{l}27 \text { Member States of the } \\
\text { European Union (excluding } \\
\text { Croatia) }\end{array}$ & $\begin{array}{l}\text { 2012: } 26751 \text { respondents } \\
\text { 2014: } 26792 \text { respondents as } \\
\text { representative Samples of the } \\
\text { population aged } \geq 15 \text { years in } \\
\text { each of the } 27 \text { EU member states } \\
\text { (excluding Croatia) and across } \\
\text { the EU in terms of age, gender } \\
\text { and area of residence. }\end{array}$ & 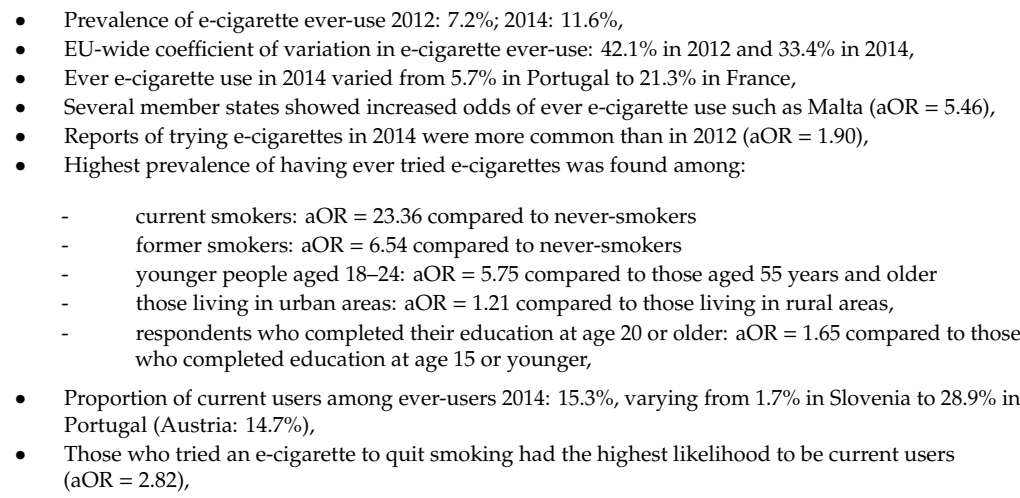 \\
\hline
\end{tabular}


Table 1. Cont.

\begin{tabular}{|c|c|c|c|c|}
\hline Citation & Data Source & Country & Sample Characteristics & Findings \\
\hline Brozek et al. 2019 [25] & $\begin{array}{l}\text { Survey performed between } \\
2017 \text { and 2018, as a part of } \\
\text { the international multi-center } \\
\text { cross-sectional study, Young } \\
\text { People E-Smoking Study } \\
\text { (YUPESS) }\end{array}$ & $\begin{array}{l}\text { Belarus, Lithuania, Poland, } \\
\text { Russia and Slovakia }\end{array}$ & $\begin{array}{c}14,352 \text { university students aged } \\
18-34 \text { years }\end{array}$ & 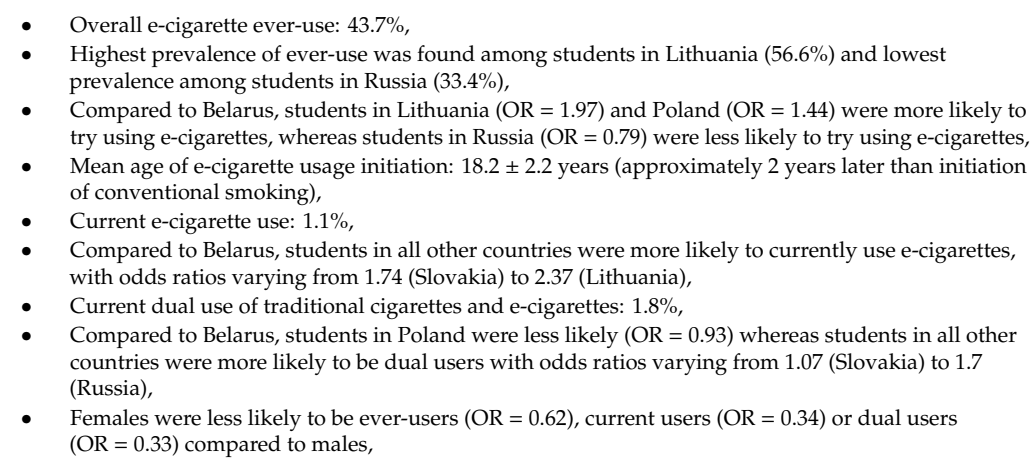 \\
\hline
\end{tabular}

- Overall prevalence of e-cigarette ever-use: $11.8 \%$ of which $70 \%$ had only tried out e-cigarettes, Prevalence of ever-use among:

- $\quad$ smokers: $32.7 \%$; never-smokers: $2.3 \%$

- $\quad$ ex-smokers who had quit smoking after 2010: $24.5 \%$; ex-smokers who had quit smoking

before $2010: 1.8 \%$

- Overall prevalence of current regular use of e-cigarettes: $1.4 \%$,

- Current regular use among:

- current smokers: $4.3 \%$, never-smokers: $0.1 \%$, ex-smokers who had quit smoking after 2010 $5.6 \%$,

2016 computer-assisted figure questionnaire
Germany 4002 randomly-chosen pers 4 and older
- Overall Prevalence of former regular use: $2.2 \%$,
- Former regular use among:

current smokers: $6.0 \%$, never-smokers: $0.3 \%$, ex-smokers who had quit smoking after 2010

- Special groups:

- $\quad$ Age group 20-39: most frequently represented group (2.4\% current regular use, $4.4 \%$ former

Blue collar workers: above average use ( $4.6 \%$ for current regular use, $6.4 \%$ for former regular use and $14.2 \%$ for have-tried),

School students: above average in terms of "h
(5.9\%) but low regarding "current use" $(0.7 \%)$,

- The mostconnon feqency of ecigerteuseged The most common frequency of e-cigarette use: among curr 
Table 1. Cont.

\begin{tabular}{|c|c|c|c|c|}
\hline Citation & Data Source & Country & Sample Characteristics & Findings \\
\hline Andler et al. 2016 [27] & $\begin{array}{l}2014 \text { Health } \\
\text { Barometer Survey }\end{array}$ & France & $\begin{array}{l}\text { Representative random sample } \\
\text { of } 15635 \text { individuals of the } \\
\text { French population aged } 15-75\end{array}$ & 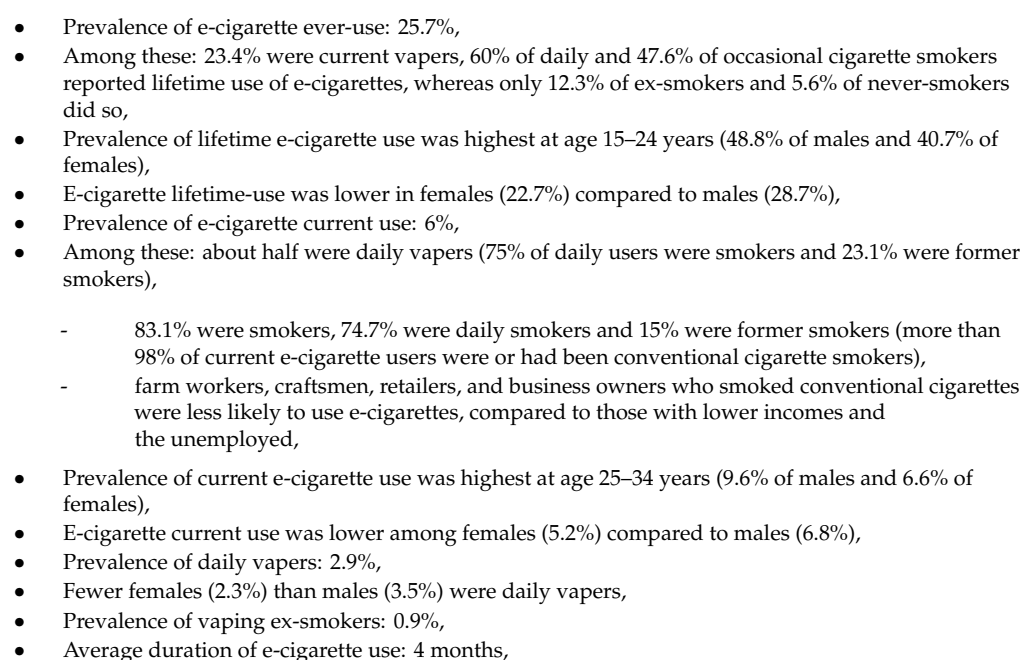 \\
\hline Kilibarda et al. 2017 [28] & $\begin{array}{l}2014 \text { National Survey on the } \\
\text { Lifestyle of Citizens of Serbia }\end{array}$ & Serbia & $\begin{array}{l}\text { A representative sample of } 5385 \\
\text { Serbians aged 18-64 years }\end{array}$ & 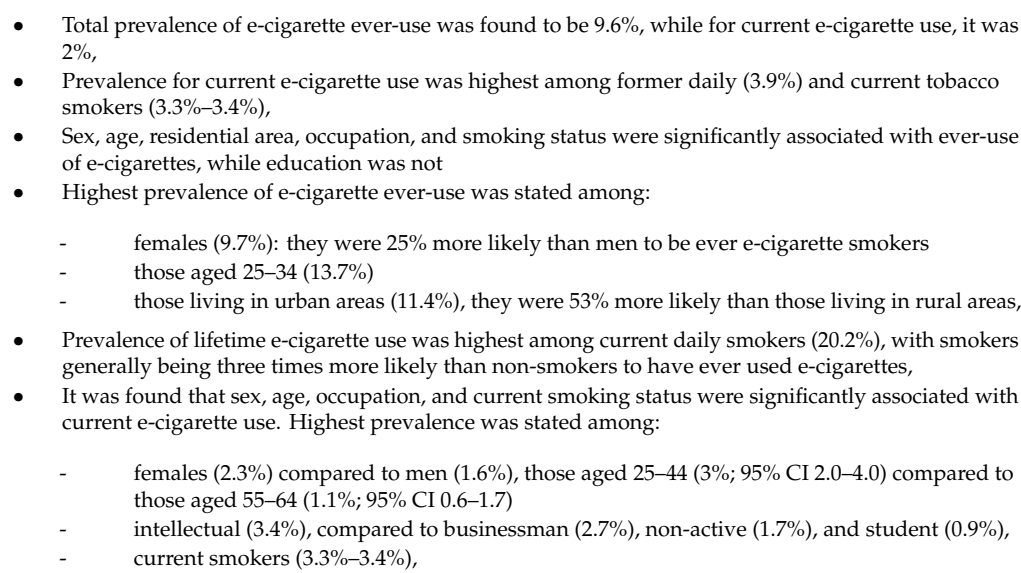 \\
\hline
\end{tabular}


Table 1. Cont

\begin{tabular}{|c|c|c|c|c|}
\hline Citation & Data Source & Country & Sample Characteristics & Findings \\
\hline Ruokolainen et al. 2017 [29] & $\begin{array}{l}2014 \text { population-based drug } \\
\text { survey }\end{array}$ & Finland & $\begin{array}{l}3485 \text { respondents out of a } \\
\text { representative random sample } \\
(\mathrm{N}=7000) \text { of Finns aged 15-69 }\end{array}$ & 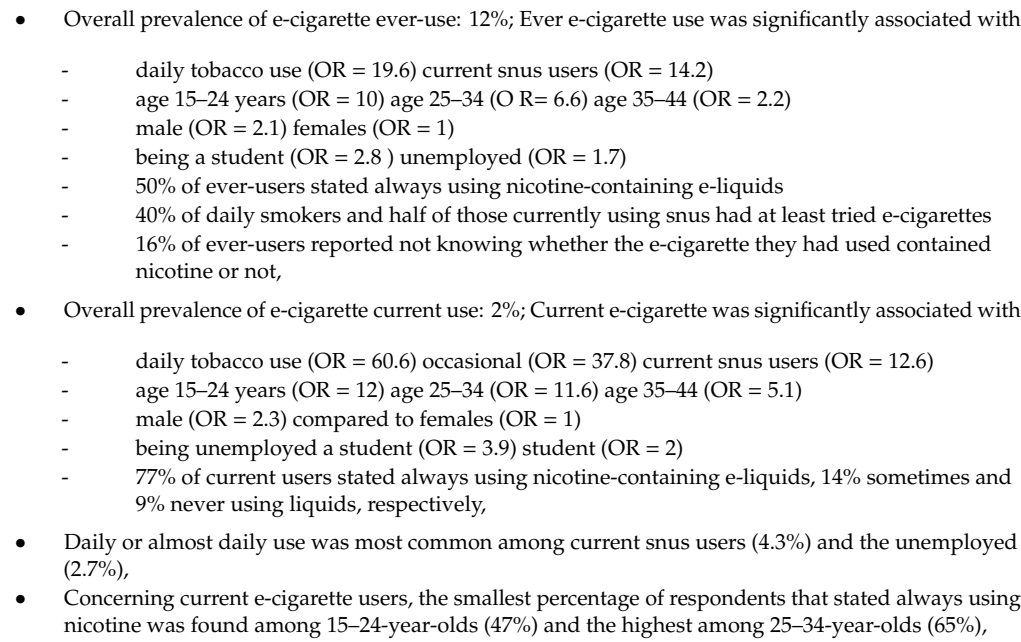 \\
\hline Gallus et al. 2014 [30] & 2013 survey on smoking & Italy & $\begin{array}{l}3000 \text { individuals aged } \geq 15 \text { years, } \\
\text { representative for the general } \\
\text { Italian population aged } 15 \text { years } \\
\text { and over. }\end{array}$ & 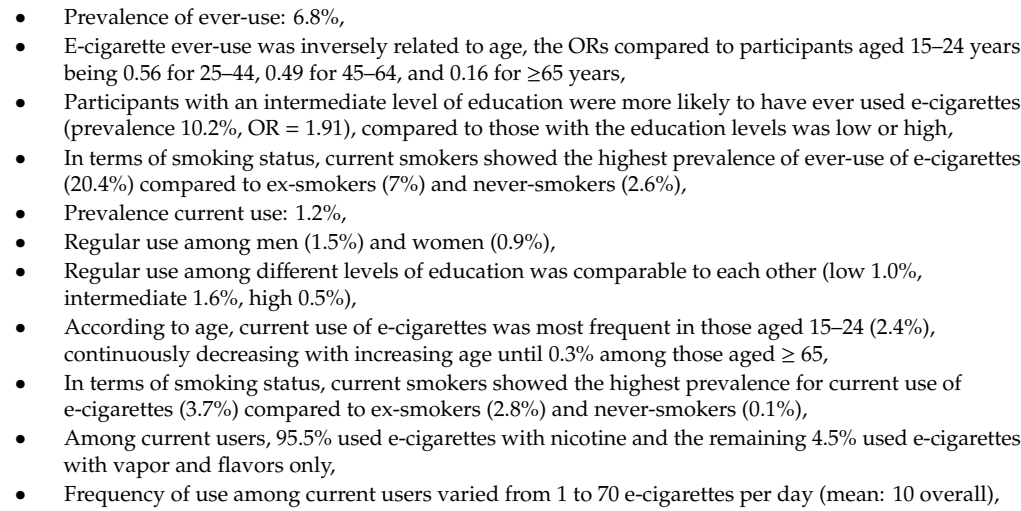 \\
\hline
\end{tabular}


Table 1. Cont

\begin{tabular}{|c|c|c|c|c|}
\hline Citation & Data Source & Country & Sample Characteristics & Findings \\
\hline Kock et al. 2019 [31] & $\begin{array}{l}\text { Monthly repeat household } \\
\text { survey between January } 2014 \\
\text { and December } 2017 \\
\text { (Smoking Toolkit Study) }\end{array}$ & England & $\begin{array}{l}\text { The Smoking Toolkit Study } \\
\text { involved 1700-1800 adults aged } \\
\text { 16+ living in households in } \\
\text { England }\end{array}$ & $\begin{array}{l}\text { - Current e-cigarette use among all adults: } 5.5 \% \text {, } \\
\text { - } \quad \text { respondents from the lowest of } 5 \text { social grades were twice as likely to use e-cigarettes } \\
\text { compared with those from the highest grade, } \\
\text { past-year smokers: } 21.3 \% \text {, } \\
\text { - } \quad \text { respondents from the } 3 \text { lowest social grades had significantly lower odds of e-cigarette use } \\
\text { - } \quad \text { smpared with those from the highest grade, } \\
\text { - } \quad \text { no significicant associations across the overall period between social grades and prevalence of } \\
\text { - } \text {-cigarette use among smokers attempting to quit, } \\
\text { - long term ex-smokers: } 5.9 \% \text {, } \\
\text { - respondents from the second and third lowest social grades were twice as likely to use } \\
\text { - } \quad \text { e-cigarettes compared with respondents from the highest grade, } \\
\text { the trend of ex-smokers using e-cigarettes increased from } 2014 \text { to } 2017 \text { across all social grades, }\end{array}$ \\
\hline Jawad et al. 2015 [32] & $\begin{array}{l}\text { Survey in public street } \\
\text { settings conducted between } \\
\text { March } 2013 \text { and March } 2014\end{array}$ & Southeast London (England) & $\begin{array}{l}1176 \text { adults of any age in six } \\
\text { southeast, ethnically diverse } \\
\text { London boroughs }\end{array}$ & $\begin{array}{l}\text { - Prevalence of ever e-cigarette use: } 7.4 \% \text {, } \\
\text { - Among these: } 47.1 \% \text { were currently non-cigarette users, } \\
\text { E-cigarette use was significantly associated with younger age groups: those aged } 18-24 \text { used more } \\
\text { e-cigarettes ( }(14.2 \% \text { than those aged } 55 \text { years and over }(1.3 \%) \text {, } \\
\text { - } \quad \text { non-white ethnicities: } 14.9 \% \text {, compared to } 5.6 \% \text { among those of white ethnicity, } \\
\text { - } \quad \text { use of waterpipe tobacco: } 20.6 \% \text { of waterpipe tobacco smokers used e-cigarettes compared to } \\
\quad 1.5 \% \text { of non-waterpipe tobacco smokers, }\end{array}$ \\
\hline Martinez-Sanchez et al. 2014 [33] & $\begin{array}{l}\text { Survey conducted between } \\
\text { May } 2013 \text { and February } 2014 \\
\text { in the course of the } \\
\text { longitudinal study, The } \\
\text { Determinants of Cotinine } \\
\text { phase } 3 \text { project }\end{array}$ & Barcelona (Spain) & $\begin{array}{l}\text { A representative sample of the } \\
\text { adult }(\geq 16 \text { years old) population } \\
\text { of Barcelona ( } \mathrm{n}=736)\end{array}$ & 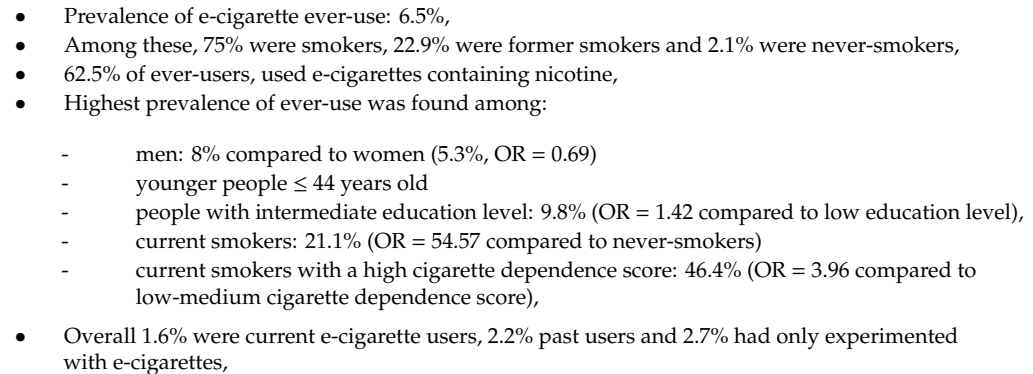 \\
\hline
\end{tabular}


Table 1. Cont

\begin{tabular}{|c|c|c|c|c|}
\hline Citation & Data Source & Country & Sample Characteristics & Findings \\
\hline Goniewicz et al. 2012 [34] & $\begin{array}{l}\text { A survey among high school } \\
\text { and university students } \\
\text { conducted between } \\
\text { September } 2010 \text { and June } \\
2011\end{array}$ & Poland & $\begin{array}{l}20240 \text { students enrolled at } 176 \\
\text { nationally-representative Polish } \\
\text { high schools and universities, } \\
\text { aged 15-24 years, of which } \\
13250 \text { responded to questions } \\
\text { about e-cigarettes }\end{array}$ & 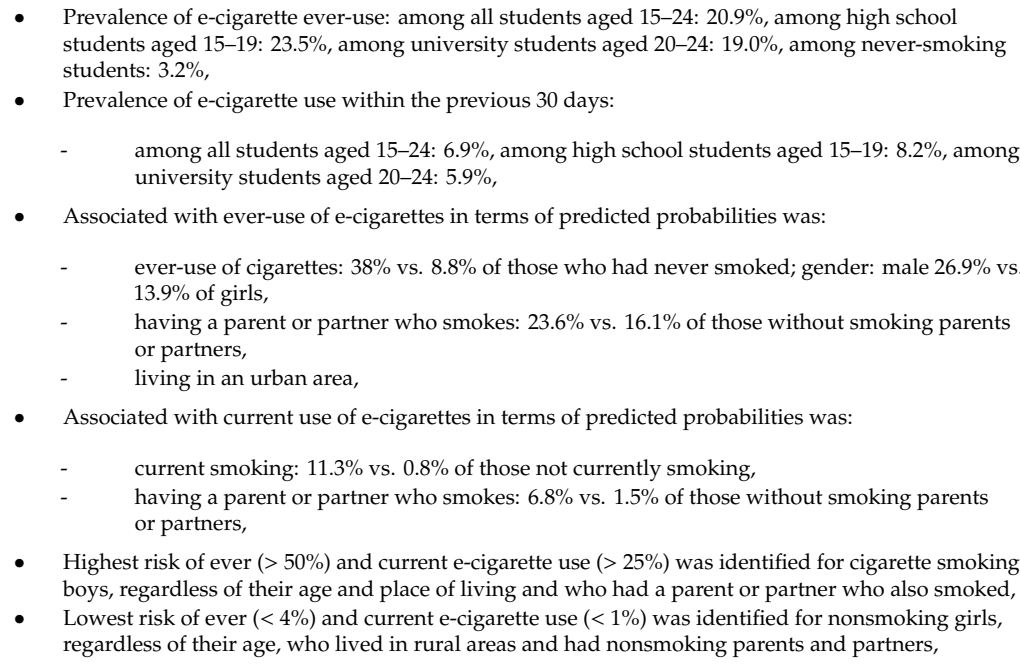 \\
\hline Kaleta et al. 2016 [35] & $\begin{array}{c}\text { The survey adapted from the } \\
\text { Global Youth Tobacco Survey } \\
\text { was conducted between } \\
\text { November } 2014 \text { and May } \\
2015\end{array}$ & $\begin{array}{l}\text { Piotrkowski District } \\
\text { (Poland) }\end{array}$ & $\begin{array}{l}3552 \text { secondary and high school } \\
\text { students aged } 13-19 \text { years from } \\
\text { Piotrkowski District (2645 } \\
\text { secondary school students and } \\
907 \text { high school students) }\end{array}$ & 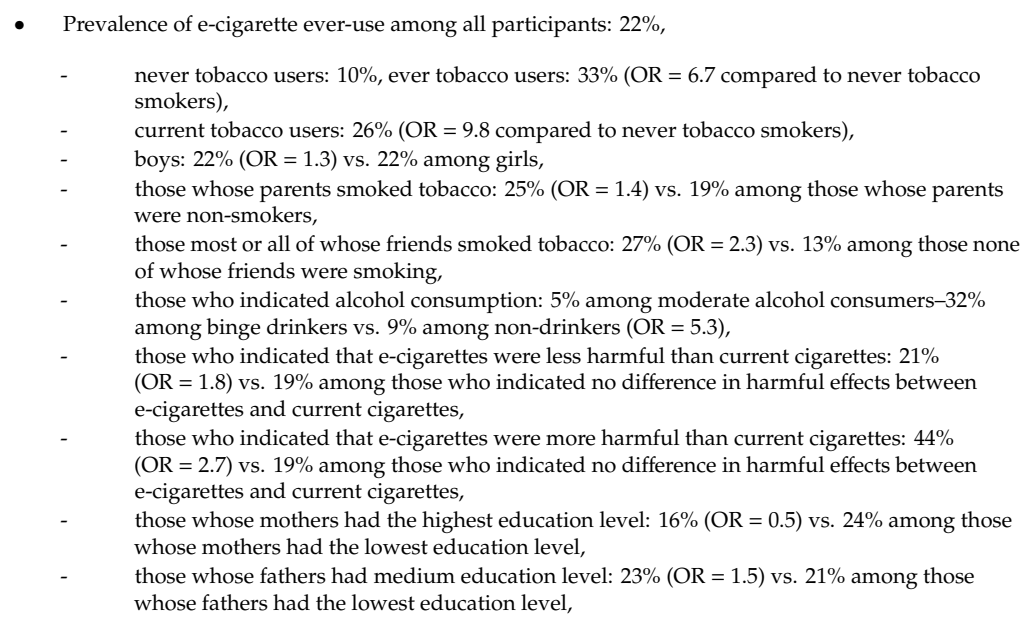 \\
\hline
\end{tabular}


Table 1. Cont.

Citation

Sample Characteristics

Finding

- Prevalence of current e-cigarette use in the past month among all participants: $27 \%$,

never tobacco users: $6 \%$, ever tobacco users: $27 \%$ (OR $=7.5$ compared to never tobacco smokers),

current tobacco users: $58 \%$ (OR $=32.5$ compared to never tobacco smokers),

boys: $32 \%(\mathrm{OR}=1.7)$ vs. $21 \%$ among girls,

those whose parents smoked tobacco: $33 \%(\mathrm{OR}=1.4)$ vs. $23 \%$ among those whose parents were non-smokers,

those whose most or all of whose friends smoked tobacco: $48 \%(\mathrm{OR}=4.5)$ vs. $13 \%$ among those none of whose friends were smoking,

those who indicated alcohol consumption: 5\% among moderate alcohol consumers - 41\%

among binge drinkers vs. $12 \%$ among non-drinkers $(\mathrm{OR}=4.3)$,

hose who indicated $(\mathrm{OR}=2.1)$ vs. $29 \%$ among those who indicated no difference in harmful effects between e-cigarettes and current cigarettes,

The survey adapted from the

Global Youth Tobacco Survey

was conducted between

2015$$
5
$$

(Poland) students aged 13-19 years from Piotrkowski District (2645 secondary school students and
Kaleta et al. $2016[3$ hose who indicated that e-cigarettes were more harmful than current cigarettes: $15 \%$

(O)

those whose mothers had the high

whe those whose fathers had the highest education level: $17 \%(\mathrm{OR}=0.6)$ vs. $33 \%$ among those whose fathers had the lowest education level,

- Predictors of continued e-cigarette use were:

male gender: $\mathrm{OR}=1.4$ compared to female gender

current tobacco smoking: $\mathrm{OR}=3.0$ compared never tobacco smoking

lack of knowledge about a ban on smoking in the school: OR $=1.4$ compared to $\mathrm{a}$ ban on smoking in the school,

- Factors that protected from current e-cigarette use were:

- higher parental education: $\mathrm{OR}=0.5$ compared to a low parental education

perception of e-cigarettes as more harmful than tobacco cigarettes: $\mathrm{OR}=0.2$ compared to the perception of e-cigarettes being as harmful as tobacco cigarettes, 
Table 1. Cont.

\begin{tabular}{|c|c|c|c|c|}
\hline Citation & Data Source & Country & Sample Characteristics & Findings \\
\hline Moore et al. 2015 [36] & $\begin{array}{l}\text { Two data sets:2014 Child } \\
\text { Exposure to Tobacco Smoke } \\
\text { (CHETS) survey ('CHETS } \\
\text { Wales 2') and 2014 Welsh } \\
\text { Heatlth Behaviour in } \\
\text { School-aged Children (HBSC) } \\
\text { Survey ('HBSC Wales') }\end{array}$ & Wales & $\begin{array}{l}\text { CHETS Wales 2: } 1601 \text { school } \\
\text { children in Year } 6 \text { (aged 10-11) } \\
\text { within a nationally } \\
\text { representative sample of 75 } \\
\text { primary schools and HBSC: } \\
9055 \text { school students aged 11-16 } \\
\text { in a nationally representative } \\
\text { sample of } 82 \text { secondary schools }\end{array}$ & 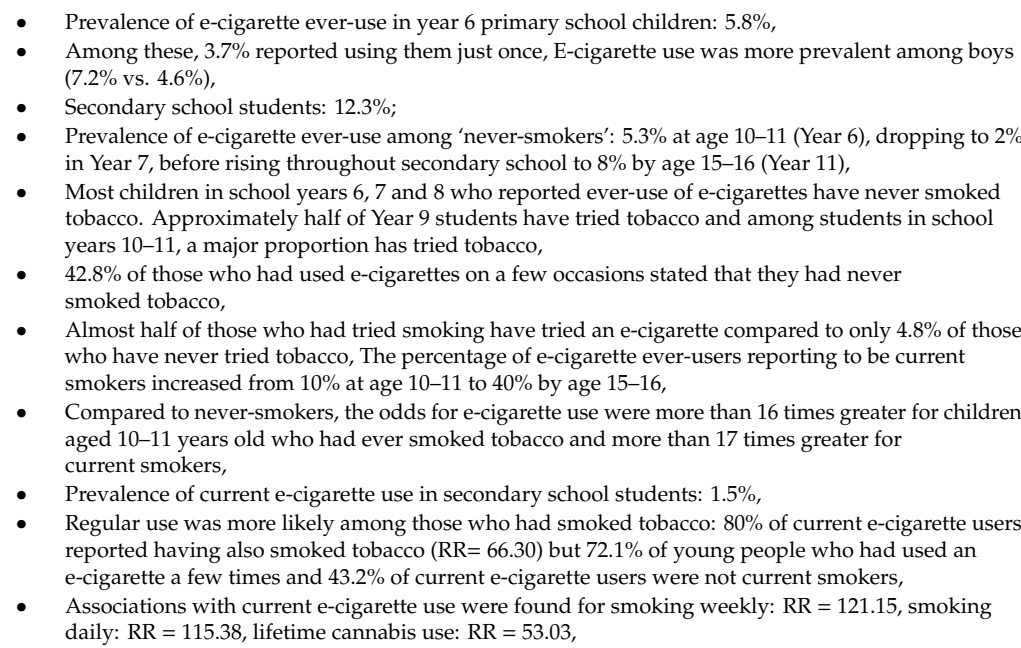 \\
\hline Kinnunen et al. 2015 [37] & $\begin{array}{l}2013 \text { nationwide Adolescent } \\
\text { Health and Lifestyle Survey }\end{array}$ & Finland & $\begin{array}{c}\text { A nationally representative } \\
\text { sample of } 9398 \text { individuals aged } \\
12,14,16 \text { and } 18 \text { years, of which } \\
3535 \text { responded to the } \\
\text { questionnaire }\end{array}$ & 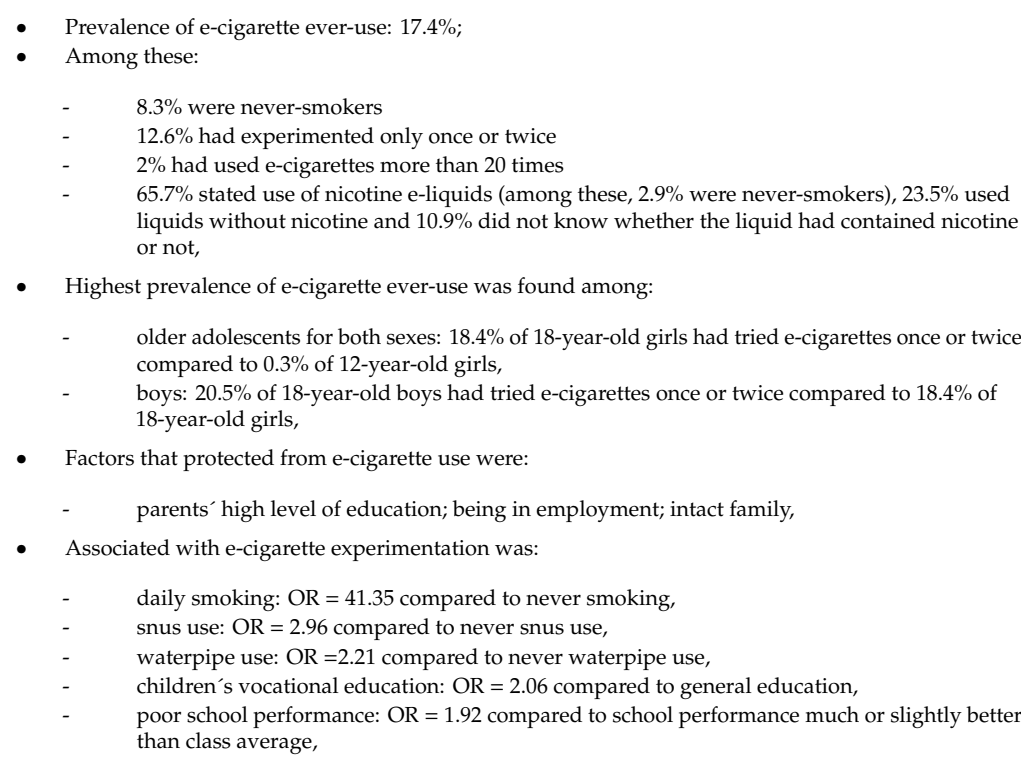 \\
\hline
\end{tabular}


Table 1. Cont.

\begin{tabular}{|c|c|c|c|c|}
\hline Citation & Data Source & Country & Sample Characteristics & Findings \\
\hline Treur et al. 2018 [38] & $\begin{array}{c}\text { The survey among cohort I } \\
\text { was conducted in 2014-2015 } \\
\text { and the survey among cohort } \\
\text { II was conducted in } \\
2016-2017\end{array}$ & Netherlands & $\begin{array}{l}\text { Cohort I: } 6819 \text { adolescents from } \\
19 \text { secondary schools across the } \\
\text { Netherlands, aged } 11-17 \text { years; } \\
\text { Cohort II: } 2758 \text { adolescents from } \\
14 \text { educational institutes in the } \\
\text { Netherlands, aged } 14-21 \text { years }\end{array}$ & 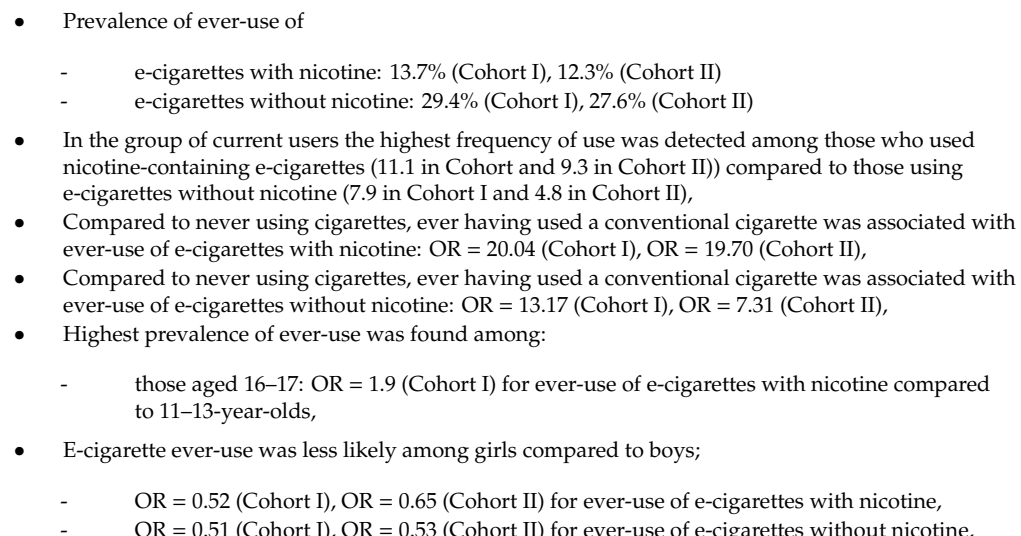 \\
\hline Dautzenberg et al. 2015 [39] & $\begin{array}{l}2013 \text { repeated school-based } \\
\text { survey }\end{array}$ & Paris (France) & $\begin{array}{l}\text { A randomly selected, } \\
\text { representative sample of } 2 \% \text { of } \\
\text { schoolchildren }(\mathrm{n}=3279) \text { of the } \\
\text { city of Paris aged } 12-19 \text { years }\end{array}$ & 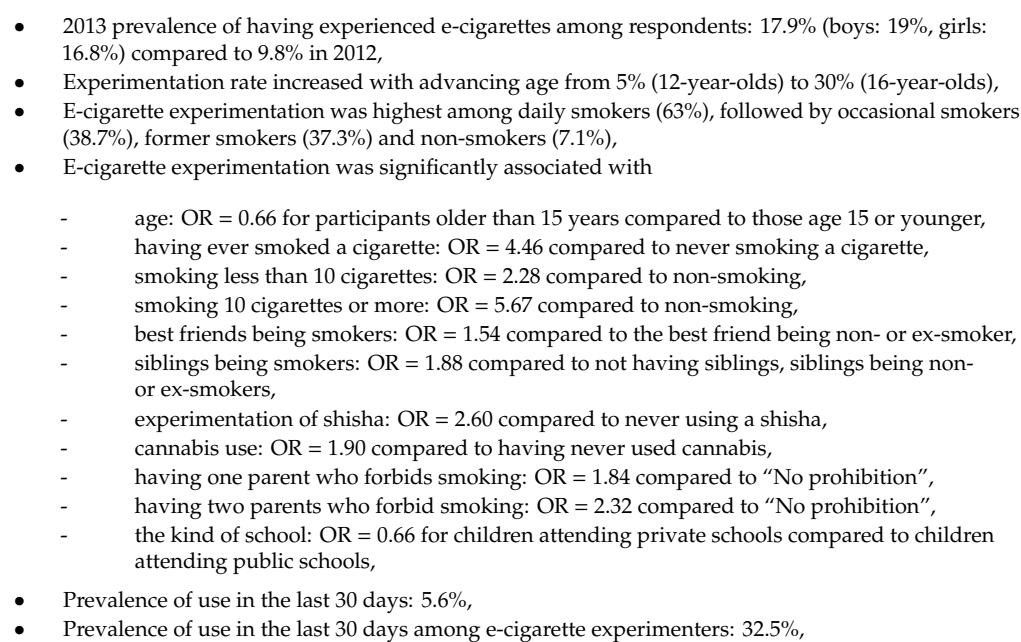 \\
\hline
\end{tabular}


Table 1. Cont

\begin{tabular}{|c|c|c|c|c|}
\hline Citation & Data Source & Country & Sample Characteristics & Findings \\
\hline Rennie et al. 2016 [40] & $\begin{array}{l}\text { Survey conducted in Winter } \\
\text { of 2014-2015 }\end{array}$ & $\begin{array}{l}\text { Hauts-de-Seine region } \\
\text { (France) }\end{array}$ & $\begin{array}{l}1486 \text { participants in their first } \\
\text { year of "lycée", aged } 16 \text { years, of } \\
\text { which } 1478 \text { answered questions } \\
\text { concerning e-cigarettes }\end{array}$ & $\begin{array}{l}\text { - Prevalence of e-cigarette experimentation: } 54 \% \text {, } \\
\text { - Among these, } 20 \% \text { had never tried standard cigarettes, } \\
\text { - } \quad \text { higherimentation with e-cigarettes was predicted by } \mathrm{OR}=1.30 \text { (compared to younger participants in terms of above and below } \\
\text { - } \quad \text { hedian age), } \\
\text { - } \quad \text { mater socioeconomic status: } \mathrm{OR}=1.10 \text { (compared to lower socioeconomic status), } \\
\text { - } \quad \text { paternal smoking of standard cigarettes: } \mathrm{OR}=1.63 \text { (compared to maternal nonsmoking), } \\
\text { - male gender: } \mathrm{OR}=1.21 \text { (compared to female gender), }\end{array}$ \\
\hline Babineau et al. 2015 [41] & $\begin{array}{l}2014 \text { survey on e-cigarette } \\
\text { use, tobacco use, and socio- } \\
\text { demographic items }\end{array}$ & Ireland & $\begin{array}{l}\text { A representative sample of } 821 \\
\text { young people from } 16 \\
\text { secondary schools in their fifth } \\
\text { year of secondary school, aged } \\
16-17\end{array}$ & 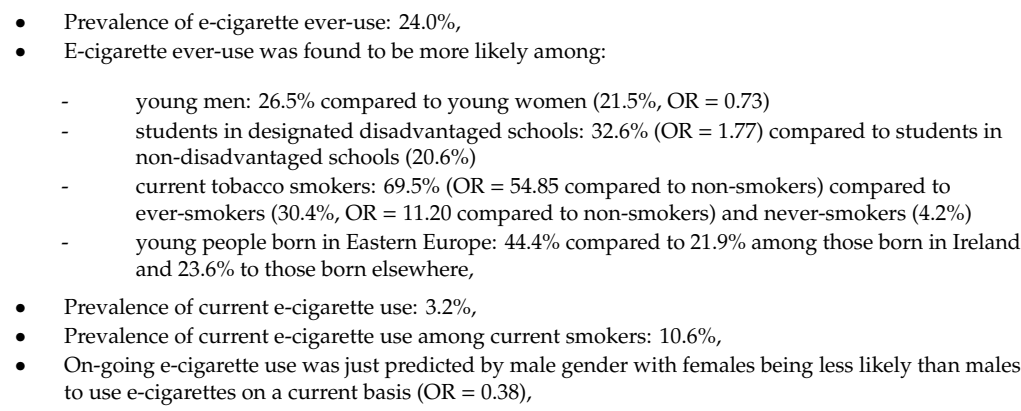 \\
\hline Geidne et al. 2016 [42] & $\begin{array}{c}2014 \text { survey as part of a study } \\
\text { on "School as a setting for } \\
\text { ANDT (Alcohol, Narcotics, } \\
\text { Doping, Tobacco) } \\
\text { prevention" }\end{array}$ & Sweden & $\begin{array}{l}665 \text { participants from four } \\
\text { municipalities in compulsory } \\
\text { school, grade } 9 \\
\text { (15-16-year-olds) }\end{array}$ & 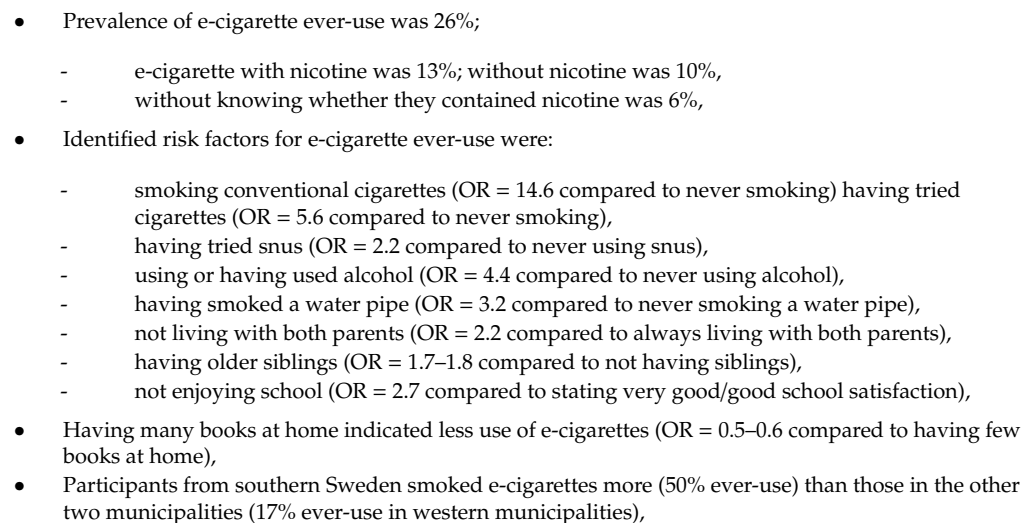 \\
\hline
\end{tabular}


Table 1. Cont.

\begin{tabular}{|c|c|c|c|c|}
\hline Citation & Data Source & Country & Sample Characteristics & Findings \\
\hline Douptcheva et al. 2013 [43] & $\begin{array}{l}\text { Analysis as part of the Cohort } \\
\text { Study on Substance Use Risk } \\
\text { Factors (C-SURF), with data } \\
\text { collected between August } \\
2010 \text { and February } 2013\end{array}$ & Switzerland & $\begin{array}{l}5081 \text { young Swiss men enrolled } \\
\text { during mandatory visits at } \\
\text { army recruitment centers }\end{array}$ & $\begin{array}{l}\text { - Use of e-cigarettes in the past } 12 \text { months among: } \\
-\quad \text { all participants: } 4.9 \% \text {; among these, } 12.0 \% \text { used them daily, } \\
-\quad \text { current smokers: } 9.3 \% \text {; among these, } 12.2 \% \text { used them daily, } \\
-\quad \text { former smokers: } 1.6 \% \text {; among these, } 13.6 \% \text { used them daily, } \\
\text { - never-smokers: } 0.4 \% \text { (no daily use), } \\
\text { - E-cigarette use among current smokers was significantly associated with secondary education: } \\
\text { OR = } 1.5 \text { compared to tertiary or primary education, } \\
\text { - German-speaking region: } \mathrm{OR}=1.3 \text { compared to French-speaking region, }\end{array}$ \\
\hline
\end{tabular}

Note: $\mathrm{CI}$ = confidence interval; $\mathrm{OR}$ = odds ratio; aOR = adjusted odds ratio; $\mathrm{RR}$ = relative risk ratio; bold indicates the prevalence of e-cigarette ever-use, current, current, or daily use 


\subsection{Prevalence of Using E-Cigarettes in the General Population}

In Table 1, the findings regarding the use of e-cigarettes in the general population are summarized. The prevalence of current e-cigarette smokers (the definition of current use of e-cigarettes varied among the surveys, from "vaped at least one e-cigarette in the last 30 days" to "at least one e-cigarette per day at the moment of the survey") ranged from $0.2 \%$ to $27 \%$, those who reported ever trying ranged from $5.5 \%$ to $56.6 \%$, and between $1 \%$ and $2.9 \%$ were found to be daily e-cigarette users. There were differences in age among participants who had tried e-cigarettes. The highest prevalence was found among those aged $10-24$ years (5.5\% to $56.6 \%$ ), followed by those aged $25-39$ (13.7\% to $25 \%$ ), $40-65$ (5\% to $6.7 \%)$, and those aged $\geq 65$ years (1.3\% to $1.6 \%)$. For example, in a sample of 5385 Serbians, there were about 3 times more current e-cigarette users among 25-44-year-olds than among 55-64-year-olds ( $3 \%$ vs. $1.1 \%$ ) [28]. It seems to point to a trend that with increasing age, the use of e-cigarettes decreases.

\subsection{Spacial Differences in Using E-Cigarettes within the WHO European Region}

European regions showed a varying picture; southern regions showed similarities, with the reported prevalence of ever-use in Italy and Spain ranging from $5.6 \%$ to $6.5 \%$. In northern regions, however, the prevalence ranged from $12 \%$ to $17.4 \%$ in Finland, to up to $26 \%$ in Sweden. We also observed differences between western and eastern European regions. Low prevalence was mostly found in western European countries, with the following prevalence rates: France (17.9\% to 54\%) Netherlands (29.4\%), Ireland (24\%), Germany (11.8\%), England (7.4\%), Wales (5.8\%), and the lowest prevalence in Switzerland (4.9\%). In comparison, highest prevalence was reported among eastern European countries, with highest being in Lithuania (56.65\%), followed by Poland ( $20.9 \%$ to $45 \%$ ), Belarus (42.7\%), Slovakia (34.4\%), Russia (33.4\%), and with considerably lower prevalence of ever-use being reported in Serbia (less than 10\%). Thus in general, the results indicate higher prevalence among eastern WHO European region countries.

\subsection{Gender and Ethnic Difference}

Men showed higher prevalence rates of e-cigarettes use than women. In included studies, men showed up to 5 times higher prevalence of e-cigarette use than women. Further, daily use was more common among men (1.5\%) than among women (0.9\%). In the study of Jawad et al. (2015), differences among ethnic groups are reported. When comparing Caucasians with other ethnicities, studies report more use among other ethnic groups (14.9\% versus 5.6\%; adjusted OR 1.76, 95\% CI 1.13 to 2.73 ) [32].

\subsection{Socio-Economic Differences}

Studies from Italy [30] and Spain [33] show that participants with secondary school education were more likely to have ever used e-cigarettes than those who reported their educational level as being "low" or "high". Current use among participants with differing educational levels ranged from $0.5 \%$ in those reporting high educational level, to $1 \%$ in those with low, and $1.6 \%$ in those with secondary level. Different results are shown in an English study reporting differences in e-cigarette use, in which smokers with a higher social grade (based on occupation) also showed higher e-cigarette use than those with a lower social grade [31]. The use of e-cigarettes in long-term ex-smokers increased over time among all groups, and was far more common in groups with lower socio-economic status. In the analyses, respondents were stratified by socio-economic status using the National Readership Survey classification system for social grade based on the occupation of the main income earner, which has useful discriminatory power as a target group indicator [31]. In addition, a study from Poland shows that participants whose parents had a primary-level education indicated current e-cigarette use more frequently than those whose parents had a tertiary-education level [35].

In terms of employment status and household income, the odds of being an ever e-cigarette user increased with lower income and unemployment $(\mathrm{OR}=2.9)$, as compared to those with employment and higher income. Among respondents who had at least tried e-cigarettes, socio-economic differences 
showed the highest prevalence among the unemployed (25\%), manual workers (29\%), students (19\%), and the self-employed $(18 \%)$, followed by other white-collar workers $(16 \%)$, managers $(12 \%)$, housewives ( $8 \%$ ), and retired persons (6\%) [22].

\subsection{E-Cigarette Use and Smoking Status}

Current smokers of conventional cigarettes showed the highest prevalence for ever-use of e-cigarettes, ranging from $20.4 \%$ to $83.1 \%$. This is followed by ex-smokers, with prevalence rates ranging from $7 \%$ to $15 \%$. Using e-cigarettes was rare among non-smokers, with a prevalence ranging from $2.3 \%$ to $5.6 \%$ for ever-use. For example, a cross-sectional survey of a French population aged 15-75 years old showed that more than $98 \%$ of current e-cigarette users were, or had been, conventional cigarette smokers [27].

The concern that young people who use e-cigarettes may be more likely to smoke cigarettes in the future [44] can be partly confirmed by the study of Treur et al. (2018) [38]. Adolescents who ever used an e-cigarette with nicotine were 11.90 more likely (95\% CI 3.36 to 42.11 ) to smoke a conventional cigarette 6 months later than those who never used an e-cigarette with nicotine. On the contrary, the odds of smoking a conventional cigarette 6 months after smoking an e-cigarette without nicotine were 5.36 (95\% CI 2.73 to 10.52) and 5.36 (95\% CI 2.78 to 10.31) for water pipe. An additional study shows that the percentage of e-cigarette ever-users and reported current smokers increased from $6.9 \%$ among 10-11-year-olds to 39.2\% among 15-16-year-olds. Current use of e-cigarettes was more likely among those who had previously smoked tobacco. Eighty percent of current e-cigarette users reported having also smoked cigarettes, compared to $72.1 \%$ of young people who had used an e-cigarette a few times, and $43.2 \%$ of current e-cigarette users were not current smokers [36].

\subsection{Type of E-Cigarette Used (Nicotine or Non-Nicotin)}

One study reports that $77 \%$ of the current e-cigarette users always used nicotine-containing e-liquids, $14 \%$ sometimes, and $9 \%$ never used nicotine-containing e-liquids. Fifty percent of ever-users stated always using nicotine-containing e-liquids [29]. Another study shows that among current users, $95.5 \%$ used e-cigarettes with nicotine and the remaining $4.5 \%$ used e-cigarettes with vapor and flavors only [30]. In contrast in Spain, 62.5\% of ever-users tended to use e-liquids with nicotine [33].

A different picture can be seen in the younger population. One study shows that $65.7 \%$ of e-cigarette ever-users tended to use nicotine e-liquids (among these, 2.9\% were never-smokers), $23.5 \%$ used liquids without nicotine, and $10.9 \%$ did not know whether the liquid had contained nicotine or not [37]. In addition, adolescents in Sweden reported more use of e-cigarettes with nicotine (13\%) compared to e-cigarettes without nicotine (10\%) [42]. In a Dutch cohort however, the prevalence of ever-use of e-cigarettes with nicotine was $13.7 \%$ (11 to 17 years) and $12.3 \%$ (14 to 21 years), respectively, whereas the prevalence of e-cigarette use without nicotine was $29.4 \%$ (11 to 17 years), and $27.6 \%$ (14 to 21 years), respectively. In the group of current users, the mean number of times used in the past month was highest for e-cigarettes with nicotine, or $11.1(\mathrm{SD}=14.5)$ in 11-17-year-olds and $9.3(\mathrm{SD}=13.9)$ in 14-21-year-olds, compared to those using e-cigarettes without nicotine, $7.9(\mathrm{SD}=12.0)$ and 4.8 $(\mathrm{SD}=9.5)$, respectively [38].

\subsection{Trends in Using E-cigarettes}

Time trends in using e-cigarettes can be derived from the Eurobarometer, which was carried out in 2014 and 2017 with similar methods [22,23]. Data show that 1.5\% (95\% CI 1.2 to 1.8) of the adult population in the European Union in 2014 were currently e-cigarette users, compared to $1.8 \%$ (95\% CI 1.5 to 2.1) in 2017, respectively. Additionally, the prevalence of e-cigarette ever-use increased from 2012 (7.2\%) to 2017 (14.6\%) [23]. 


\subsection{Reasons for E-cigarette Use}

The most frequent reasons for starting the use of e-cigarettes were to stop or reduce tobacco consumption $(61 \%)$, because e-cigarettes were seen as less harmful $(31 \%)$, had lower costs $(25 \%)$, and that e-cigarette use is allowed in areas where regular tobacco smoking is not (15\%); other reasons included different flavors (12\%), that friends were also taking up e-cigarette smoking $(11 \%)$, and that e-cigarettes were perceived as cool or attractive (6\%) [22]. A study by Filippidis et al. (2017) of adults from 27 European countries shows that the main reason for using e-cigarettes among current e-cigarette users was that they believed e-cigarettes could help them quit smoking, and because they wanted to circumvent smoking bans [24].

A further study of people aged 14 years or over from Germany found that the main reasons for e-cigarette use in ever-users were "curiosity" (59\%), followed by "quitting tobacco use or nicotine use" $(29.1 \%)$, "complement to smoking" (7.8\%), and "other reasons" including taste and lower price $(2.1 \%)$. Current e-cigarette users most frequently named "quitting tobacco or nicotine use" (52\%), followed by "complement to smoking" (25\%), and "curiosity" (12.5\%) as their reasons. Among smokers, "quitting tobacco or nicotine use" (46\%), and among young people, "curiosity" $(73 \%)$ were the main reasons for e-cigarette use [26].

The reasons for e-cigarette use found by Andler et al. (2016) in a survey of adults from France were addiction to nicotine (three quarters of e-cigarette users), the consideration of e-cigarettes being less harmful than conventional cigarettes (named by $60 \%$ of dual users and $80 \%$ of former smokers who vaped), e-cigarettes being less expensive (stated by $66 \%$ of dual users and $71 \%$ of vaping ex-smokers), and being permitted in places where conventional cigarettes are banned (reason for $28 \%$ of dual users and $20 \%$ of vaping ex-smokers). They also found that among dual users, $69.4 \%$ wanted to quit smoking conventional cigarettes, as compared to $54.2 \%$ among non-vaping smokers [27].

\section{Discussion}

The results of our review show that the European population's lifetime-prevalence of using e-cigarettes is high, whereas prevalence of current daily smoking of e-cigarettes is quite low. In 2018, $3.2 \%$ of US adults reported current e-cigarette use [45], which is similar to our findings in the WHO European region. However, there are major differences in subpopulations in Europe. Our review shows much lower prevalence of e-cigarette use among older adults who have never smoked. However, the prevalence seems to be on the rise. In summary, daily e-cigarette use was much more common among smokers or former smokers [23]. There was evidence of variation in e-cigarette use by ethnicity and region. For example, the survey by Jawad et al. (2015) found that there was more e-cigarettes use among non-Caucasian ethnic minorities [32]. This is in line with a four-country survey (Canada, USA, United Kingdom, and Australia) from 2013 [46] that found that there was generally higher awareness of e-cigarette use among the Caucasian ethnicity compared with non-Caucasian ones. There are other disparities, such as spatial differences in e-cigarette use. People from eastern European countries used e-cigarettes more often than the European regional average. This may be due to differences in tobacco control policies and different accessibility to tobacco. For instance, Czech Republic, Slovakia, and Poland have weak implementation of smoke-free public rooms, especially in the hospitality industry [47]. Further, in poorer countries, people tend to smoke more; socioeconomic inequality is apparent in initiation: the risk that young people will start smoking is higher in less privileged groups [48]. Such disparity calls for possible policy interventions that can help accelerate the reduction of e-cigarette use in these areas.

Studies show that adolescents who ever used an e-cigarette with nicotine were more likely to smoke cigarettes in the future $[38,44]$. A large proportion of current e-cigarette users reported having also smoked cigarettes, but almost three-quarters of young people who had used an e-cigarette a few times, and almost half of current e-cigarette users, were not current smokers [36]. Further, among young adults, experimentation with e-cigarette use increased with advancing age, among daily smokers, best friends being smokers, and those whose siblings were smokers. [39,42]. Young males were also slightly 
more likely to experiment with e-cigarettes than females. The data suggest that peers may influence experimentation in young populations $[37,39,40]$. Another reason of e-cigarette experimentation may also be that sensation-seeking, or the need for new, different, or complex sensations and experiences-and the willingness to take risks to achieve them-is associated with adolescent substance use [49]. Further, studies shows that sweet flavors and smells are disproportionately appealing to youth, and are cited as a primary reason for use among this age group relative to adults [50]. On the basis of the above, regulation of flavor chemicals in e-cigarette products should be addressed, given that preferences for specific sweet flavors predicted e-cigarette use exclusively among youth. Overall, these results provide some support for the hypothesis that e-cigarettes act as a gateway to conventional cigarette smoking, though other explanations for the association are possible. The findings of high prevalence of use among adolescents and young adults suggest that e-cigarettes have the potential to expand the nicotine market in these age groups and may have the effect of renormalising smoking. Further monitoring and research to investigate these issues is required.

\section{Limitations \& Directions for Future Research}

One limitation is that only one author conducted the narrative review process. It is possible that another reviewer may have included additional information. However, our study is based on published evidence and offers an overview of the use of electronic cigarettes in European populations.

The findings are limited by the quality of the methods of the surveys in the included studies. For example, some questionnaires were not validated, thus the extent to which they capture true prevalence is unclear, as is the extent to which this affected the internal validity of the findings. Furthermore, wording of questions assessing e-cigarettes may have changed, potentially introducing misclassification bias. A lack of a unified definition of what constitutes "use" of an e-cigarette is also a challenge for the survey research, while measures should aim to also capture, for example, "current daily use" or other factors.

\section{Conclusions}

Overall, the results suggest that e-cigarettes are used predominantly by smokers and former smokers. There is a higher prevalence of e-cigarette use among males, adolescents, and young adults, as well as within populations of eastern European countries. For adolescents and young adults, additional research is recommended to identify whether e-cigarettes encourage or reduce uptake of smoking and support smoking cessation.

Author Contributions: I.G., S.H. and T.E.D. conceived the original idea. I.S. conducted the literature search. A.K. and T.E.D. provided strategies for data analysis and interpretation. A.K. and S.S. drafted the manuscript. All authors provided significant input to the submitted manuscript and approved its submission.

Funding: This research was funded by the Health Insurance Group of Styria (STGKK). The views expressed in this publication are those of the authors and do not necessarily reflect the views of the funding agency.

Conflicts of Interest: The authors declare no conflict of interest. The funding institution had no role in the interpretation of the data or in the writing of the manuscript.

\section{References}

1. Caponnetto, P.; Campagna, D.; Papale, G.; Russo, C.; Polosa, R. The emerging phenomenon of electronic cigarettes. Expert Rev. Respir. Med. 2012, 6, 63-74. [CrossRef] [PubMed]

2. Kim, J.J.; Sabatelli, N.; Tutak, W.; Giuseppetti, A.; Frukhtbeyn, S.; Shaffer, I.; Wilhide, J.; Routkevitch, D.; Ondov, J.M. Universal electronic-cigarette test: Physiochemical characterization of reference e-liquid. Tob. Induc. Dis. 2017, 15, 14. [CrossRef] [PubMed]

3. Breland, A.B.; Spindle, T.; Weaver, M.; Eissenberg, T. Science and electronic cigarettes: Current data, future needs. J. Addict. Med. 2014, 8, 223-233. [CrossRef]

4. Hartmann-Boyce, J.; McRobbie, H.; Bullen, C.; Begh, R.; Stead, L.F.; Hajek, P. Electronic cigarettes for smoking cessation. Cochrane Database Syst. Rev. 2016, 9, Cd010216. [CrossRef] 
5. Bullen, C.; Howe, C.; Laugesen, M.; McRobbie, H.; Parag, V.; Williman, J.; Walker, N. Electronic cigarettes for smoking cessation: A randomised controlled trial. Lancet 2013, 382, 1629-1637. [CrossRef]

6. Halpern, S.D.; Harhay, M.O.; Saulsgiver, K.; Brophy, C.; Troxel, A.B.; Volpp, K.G. A pragmatic trial of e-cigarettes, incentives, and drugs for smoking cessation. N. Engl. J. Med. 2018, 378, 2302-2310. [CrossRef] [PubMed]

7. Hajek, P.; Phillips-Waller, A.; Przulj, D.; Pesola, F.; Myers Smith, K.; Bisal, N.; Li, J.; Parrott, S.; Sasieni, P.; Dawkins, L. A randomized trial of e-cigarettes versus nicotine-replacement therapy. N. Engl. J. Med. 2019, 380, 629-637. [CrossRef]

8. Grabovac, I.; Oberndorfer, M.; Fischer, J.; Wiesinger, W.; Haider, S.; Dorner, T.E. Effectiveness of E-Cigarettes in Smoking Cessation: A Systematic Review and Meta-Analysis. 2020. submitted manuscript.

9. McNeill, A.; Brose, L.S.; Calder, R.; Bauld, L.; Robson, D. Vaping in England: An evidence update February 2019. Available online: https://www.gov.uk/government/publications/vaping-in-england-an-evidenceupdate-february-2019 (accessed on 4 October 2019).

10. Patnode, C.D.; Henderson, J.T.; Thompson, J.H.; Senger, C.A.; Fortmann, S.P.; Whitlock, E.P. Behavioral counseling and pharmacotherapy interventions for tobacco cessation in adults, including pregnant women: A review of reviews for the US Preventive Services Task Force. Ann. Intern. Med. 2015, 163, 608-621. [CrossRef]

11. Bhatnagar, A.; Whitsel, L.P.; Ribisl, K.M.; Bullen, C.; Chaloupka, F.; Piano, M.R.; Robertson, R.M.; McAuley, T.; Goff, D.; Benowitz, N. Electronic cigarettes: A policy statement from the American Heart Association. Circulation 2014, 130, 1418-1436. [CrossRef]

12. National Academies of Sciences, Engineering and Medicine. Health, Medicine, Division Board on Population, Health; Public Health. In Public Health Consequences of, E-Cigarettes; Eaton, D.L., Kwan, L.Y., Stratton, K., Eds.; National Academies Press (US) Copyright 2018 by the National Academy of Sciences: Washington, DC, USA, 2018.

13. Blount, B.C.; Karwowski, M.P.; Shields, P.G.; Morel-Espinosa, M.; Valentin-Blasini, L.; Gardner, M.; Braselton, M.; Brosius, C.R.; Caron, K.T.; Chambers, D.; et al. Vitamin E Acetate in Bronchoalveolar-Lavage Fluid Associated with EVALI. N. Engl. J. Med. 2019. [CrossRef] [PubMed]

14. Moritz, E.D.; Zapata, L.B.; Lekiachvili, A.; Glidden, E.; Annor, F.B.; Werner, A.K.; Ussery, E.N.; Hughes, M.M.; Kimball, A.; DeSisto, C.L. Update: Characteristics of patients in a national outbreak of E-cigarette, or vaping, product use-associated lung injuries-United States, October 2019. Morb. Mortal. Wkly. Rep. 2019, 68, 985. [CrossRef] [PubMed]

15. Krishnasamy, V.P. Update: Characteristics of a Nationwide Outbreak of E-cigarette, or Vaping, Product Use-Associated Lung Injury-United States, August 2019-January 2020. Morb. Mortal. Wkly. Rep. 2020, 69, 90-94. [CrossRef] [PubMed]

16. Health, U.D.O.; Services, H. E-Cigarette Use among Youth and Young Adults. A Report of the Surgeon General. Available online: https://e-cigarettes.surgeongeneral.gov/documents/2016_SGR_Full_Report_non-508.pdf (accessed on 9 October 2019).

17. Zhong, J.; Cao, S.; Gong, W.; Fei, F.; Wang, M. Electronic Cigarettes Use and Intention to Cigarette Smoking among Never-Smoking Adolescents and Young Adults: A Meta-Analysis. Int. J. Environ. Res. Public Health 2016, 13, 465. [CrossRef]

18. Jaber, R.M.; Mirbolouk, M.; DeFilippis, A.P.; Maziak, W.; Keith, R.; Payne, T.; Stokes, A.; Benjamin, E.; Bhatnagar, A.; Blankstein, R. Electronic cigarette use prevalence, associated factors, and pattern by cigarette smoking status in the United States from NHANES (National Health and Nutrition Examination Survey) 2013-2014. J. Am. Heart Assoc. 2018, 7, e008178. [CrossRef]

19. Chapman, S.L.C.; Wu, L.T. E-cigarette prevalence and correlates of use among adolescents versus adults: A review and comparison. J. Psychiatr. Res. 2014, 54, 43-54. [CrossRef]

20. Cullen, K.A.; Ambrose, B.K.; Gentzke, A.S.; Apelberg, B.J.; Jamal, A.; King, B.A. Notes from the Field: Use of Electronic Cigarettes and any Tobacco Product among Middle and High School Students-United States, 2011-2018. Morb. Mortal. Wkly. Rep. 2018, 67, 1276-1277. [CrossRef]

21. Schoenborn, C.A.; Gindi, R.M. Electronic cigarette use among adults: United States, 2014. Morb. Mortal. Wkly. Rep. 2015, 217, 1-8. 
22. European Commission. Attitudes of Europeans towards tobacco and electronic cigarettes. Spec. Eurobarometer 2017, 458, 19-24. Available online: http://ec.europa.eu/commfrontoffice/publicopinion/index.cfm/Survey/ getSurveyDetail/instruments/SPECIAL/surveyKy/2146 (accessed on 6 September 2019).

23. Laverty, A.A.; Filippidis, F.T.; Vardavas, C.I. Patterns, trends and determinants of e-cigarette use in 28 European Union Member States 2014-2017. Prev. Med. 2018, 116, 13-18. [CrossRef]

24. Filippidis, F.T.; Laverty, A.A.; Gerovasili, V.; Vardavas, C.I. Two-year trends and predictors of e-cigarette use in 27 European Union member states. Tob. Control 2017, 26, 98-104. [CrossRef] [PubMed]

25. Brozek, G.M.; Jankowski, M.; Lawson, J.A.; Shpakou, A.; Poznanski, M.; Zielonka, T.M.; Klimatckaia, L.; Loginovich, Y.; Rachel, M.; Gereova, J.; et al. The Prevalence of Cigarette and E-cigarette Smoking among Students in Central and Eastern Europe-Results of the YUPESS Study. Int. J. Environ. Res. Public Health 2019, 16, 2297. [CrossRef] [PubMed]

26. Eichler, M.; Blettner, M.; Singer, S. The use of e-cigarettes: A population-based cross-sectional survey of 4002 individuals in 2016. Dtsch. Arztebl. Int. 2016, 113, 847. [PubMed]

27. Andler, R.; Guignard, R.; Wilquin, J.L.; Beck, F.; Richard, J.B.; Nguyen-Thanh, V. Electronic cigarette use in France in 2014. Int. J. Public Health 2016, 61, 159-165. [CrossRef] [PubMed]

28. Kilibarda, B.; Mravcik, V.; Martens, M.S. E-cigarette use among Serbian adults: Prevalence and user characteristics. Int. J. Public Health 2016, 61, 167-175. [CrossRef]

29. Ruokolainen, O.; Ollila, H.; Karjalainen, K. Determinants of electronic cigarette use among Finnish adults: Results from a population-based survey. Nordisk. Alkohol. Nark. 2017, 34, 471-480. [CrossRef]

30. Gallus, S.; Lugo, A.; Pacifici, R.; Pichini, S.; Colombo, P.; Garattini, S.; La Vecchia, C. E-cigarette awareness, use, and harm perceptions in Italy: A national representative survey. Nicotine Tob. Res. 2014, 16, 1541-1548. [CrossRef]

31. Kock, L.; Shahab, L.; West, R.; Brown, J. E-cigarette use in England 2014-17 as a function of socio-economic profile. Addiction 2019, 114, 294-303. [CrossRef]

32. Jawad, M.; Power, G. Waterpipe tobacco and electronic cigarette use in a southeast London adult sample: A cross-sectional analysis. J. Public Health 2015, 38, e114-e121. [CrossRef]

33. Martinez-Sanchez, J.M.; Ballbe, M.; Fu, M.; Martin-Sanchez, J.C.; Salto, E.; Gottlieb, M.; Daynard, R.; Connolly, G.N.; Fernandez, E. Electronic cigarette use among adult population: A cross-sectional study in Barcelona, Spain (2013-2014). BMJ Open 2014, 4, e005894. [CrossRef]

34. Goniewicz, M.L.; Zielinska-Danch, W. Electronic cigarette use among teenagers and young adults in Poland. Pediatrics 2012, 130, e879-e885. [CrossRef] [PubMed]

35. Kaleta, D.; Wojtysiak, P.; Polanska, K. Use of electronic cigarettes among secondary and high school students from a socially disadvantaged rural area in Poland. BMC Public Health 2016, 15, 703. [CrossRef] [PubMed]

36. Moore, G.; Hewitt, G.; Evans, J.; Littlecott, H.J.; Holliday, J.; Ahmed, N.; Moore, L.; Murphy, S.; Fletcher, A. Electronic-cigarette use among young people in Wales: Evidence from two cross-sectional surveys. BMJ Open 2015, 5, e007072. [CrossRef] [PubMed]

37. Kinnunen, J.M.; Ollila, H.; El-Amin, S.E.T.; Pere, L.A.; Lindfors, P.L.; Rimpelä, A.H. Awareness and determinants of electronic cigarette use among Finnish adolescents in 2013: A population-based study. Tob. Control 2015, 24, e264-e270. [CrossRef] [PubMed]

38. Treur, J.L.; Rozema, A.D.; Mathijssen, J.J.P.; van Oers, H.; Vink, J.M. E-cigarette and waterpipe use in two adolescent cohorts: Cross-sectional and longitudinal associations with conventional cigarette smoking. Eur. J. Epidemiol. 2018, 33, 323-334. [CrossRef] [PubMed]

39. Dautzenberg, B.; Berlin, I.; Tanguy, M.L.; Rieu, N.; Birkui, P. Factors associated with experimentation of electronic cigarettes among Parisian teenagers in 2013. Tob. Induc. Dis. 2015, 13, 40. [CrossRef] [PubMed]

40. Rennie, L.J.; Bazillier-Bruneau, C.; Rouesse, J. Harm Reduction or Harm Introduction? Prevalence and Correlates of E-Cigarette Use among French Adolescents. J. Adolesc. Health 2016, 58, 440-445. [CrossRef]

41. Babineau, K.; Taylor, K.; Clancy, L. Electronic Cigarette Use among Irish Youth: A Cross Sectional Study of Prevalence and Associated Factors. PLoS ONE 2015, 10, e0126419. [CrossRef]

42. Geidne, S.; Beckman, L.; Edvardsson, I.; Hulldin, J. Prevalence and risk factors of electronic cigarette use among adolescents: Data from four Swedish municipalities. Nordisk. Alkohol. Nark. 2016, 33, 225-240. [CrossRef]

43. Douptcheva, N.; Gmel, G.; Studer, J.; Deline, S.; Etter, J.F. Use of electronic cigarettes among young Swiss men. J. Epidemiol Community Health 2013, 67, 1075-1076. [CrossRef] 
44. Primack, B.A.; Soneji, S.; Stoolmiller, M.; Fine, M.J.; Sargent, J.D. Progression to Traditional Cigarette Smoking after Electronic Cigarette Use among US Adolescents and Young Adults. JAMA Pediatr. 2015, 169, 1018-1023. [CrossRef] [PubMed]

45. Dai, H.; Leventhal, A.M. Prevalence of e-Cigarette Use among Adults in the United States, 2014-2018. JAMA 2019, 322, 1824-1827. [CrossRef] [PubMed]

46. Hartwell, G.; Thomas, S.; Egan, M.; Gilmore, A.; Petticrew, M. E-cigarettes and equity: A systematic review of differences in awareness and use between sociodemographic groups. Tob. Control 2017, 26, e85-e91. [CrossRef] [PubMed]

47. Neuberger, M. Tobacco control: Prevention and cessation in Europe. Memo Mag. Eur. Med. Oncol. 2019, 12, 156-161. [CrossRef]

48. Bauld, L.; Judge, K.; Platt, S. Assessing the impact of smoking cessation services on reducing health inequalities in England: Observational study. Tob. Control 2007, 16, 400-404. [CrossRef]

49. Crawford, A.M.; Pentz, M.A.; Chou, C.P.; Li, C.; Dwyer, J.H. Parallel developmental trajectories of sensation seeking and regular substance use in adolescents. Psychol. Addict. Behav. 2003, 17, 179. [CrossRef]

50. Huang, L.L.; Baker, H.M.; Meernik, C.; Ranney, L.M.; Richardson, A.; Goldstein, A.O. Impact of non-menthol flavours in tobacco products on perceptions and use among youth, young adults and adults: A systematic review. Tob. Control 2017, 26, 709-719. [CrossRef]

(C) 2020 by the authors. Licensee MDPI, Basel, Switzerland. This article is an open access article distributed under the terms and conditions of the Creative Commons Attribution (CC BY) license (http://creativecommons.org/licenses/by/4.0/). 